\section{Optimized in vitro plant regeneration of the biodiesel plant Jatropha curcas L.: the effects of using seeds at different stages of maturity as starting materials}

\author{
Sillma Rampadarath, Daneshwar \\ Puchooa, Mala Ranghoo-Sanmukhiya \\ Faculty of Agriculture, University of \\ Mauritius, Réduit, Mauritius
}

\section{Abstract}

Jatropha curcas L. is an important biofuel plant that can be regenerated in vitro using seeds. The fruits of $J$. curcas do not reach maturity at the same time although they are on the same bunch. This study was undertaken to evaluate the effect of seeds, from fruits at different stages of maturity, on in vitro plantlet formation. Callus was induced on Murashige and Skoog medium using different concentrations of 2,4 dichlorophenoxyacetic acid (2,4-D) and 6 benzylaminopurine (BAP). 2,4D at a concentration of $3.0 \mathrm{mg} / \mathrm{L}$ and BAP at $1.0 \mathrm{mg} / \mathrm{L}$ were found to be optimum for callus formation. In vitro plantlets obtained on BAP were smaller with thicker hypocotyl and thicker roots. On the other hand, seeds from mature fruits gave better results for in vitro plantlet regeneration on $1.0 \mathrm{mg} / \mathrm{L}$ BAP without any rooting medium. A combination of sand and soil were used for acclimatization. Best results were obtained when sand and soil were used in equal amounts. Results also showed that seed maturity is an important factor for in vitro plant regeneration of $J$. curcas and that root formation in vitro does not require additional plant growth regulator substance.

\section{Introduction}

Plants that contain high levels of secondary metabolites are difficult to mass propagate through tissue culture. ${ }^{1}$ Jatropha curcas L. commonly known as physic nut belongs to the Euphorbiaceae family and has various desirable characteristics that make the plant very promising for the agro-energy market. ${ }^{2}$ The biofuel industry is being subjected to controversies including food insecurity due to divergence of staple crops towards biofuel production. ${ }^{3}$ The choice of proper feedstock is therefore crucial. Lipid from non-edible feedstocks is popular because they do not compete with the food market. ${ }^{4}$ Also, the prohibitive cost of edible oils prevents their use in Biodiesel preparation, but nonedible oils are affordable for biodiesel production. ${ }^{5}$ Much attention is being given to the non-edible $J$. curcas. The oil content of $J$. curcas seeds is made up of almost $60 \%$ fatty acid that has a close resemblance to the edible oils, which makes the oil a good substitute for biodiesel fuel. ${ }^{5}$ However, scarcity of seeds, delay of rooting with vegetative cuttings and poor seed germination paved way for a major need of micropropagation of J. curcas. ${ }^{6-8}$ Furthermore, to ensure a disease free explants embryo explants culture is preferred. ${ }^{8}$ There have been few studies done to date on the in vitro culture of $J$. curcas. ${ }^{9}$ In vitro regeneration of plantlets is essential for mass propagation by either organogenesis or somatic embryogenesis and it requires good starting materials. Hence, the aim of the study was to identify the most appropriate stage of maturity of the seeds and the most appropriate plant growth regulators (PGRs) combinations for plantlet regeneration and the most appropriate substrate(s) combinations for hardening of the plantlets.

\section{Materials and Methods}

\section{Plant materials}

Seeds from fruits of Jatropha curcas L. at three maturity stages were used as explants (immature - green color 30 days (d) after pollination; mature - yellow color 40d after pollination; fully mature-brown/black color - $90 \mathrm{~d}$ after pollination) in this study.

\section{Surface sterilization and culture establishment}

For surface sterilization, the seeds were first washed for 10 min with lauric acid; $40 \%$ (v/v) under running tap water. The seeds were then soaked for $24 \mathrm{~h}$ in $0.5 \mathrm{mg} / \mathrm{L}$ of benomyl and $0.5 \mathrm{mg} / \mathrm{L}$ ciprofloxacin. This was followed by rinsing in sterile distilled water and then transferring to ethanol $[70 \%(\mathrm{v} / \mathrm{v})]$ for $6 \mathrm{~min}$. The seeds were rinsed and transferred in a sodium hypochlorite solution [40\% (w/v)] for 20 min. Following another rinse, the seeds were dipped into mercuric chloride [0.02\% $(\mathrm{w} / \mathrm{v})$ ] for a further $6 \mathrm{~min}$. After a last rinse, the seed coats were cracked and the embryos were inoculated on the specific media. The $\mathrm{pH}$ of the media was adjusted to 5.8 before addition of agar and autoclaved at 15 psi at $121^{\circ} \mathrm{C}$ for $20 \mathrm{~min}$. Cultures were maintained in growth room at $23 \pm 2^{\circ} \mathrm{C}$ and $16 / 8 \mathrm{~h}$ light/dark photoperiod under light intensity of 1000 lux.

\section{Callus induction}

The embryos of the immature, mature and fully mature seeds were inoculated on Murashige and Skoog medium (MS). ${ }^{10}$ After
Correspondence: Daneshwar Puchooa, Faculty of Agriculture, University of Mauritius, Reduit, Moka, Mauritius.

Tel.: +230.454 .1041 - Fax: +230.465 .5743 .

E-mail: sudeshp@uom.ac.mu

Key words: seed maturity, plantlets, plant growth regulator substance, Jatropha curcas L.

Contributions: the authors contributed equally.

Acknowledgements: the authors are grateful to the staff of the Botany and Biotechnology Laboratories of the Faculty of Agriculture, University of Mauritius, in particular, Mrs D Bhookun-Seeruttun, Mrs A. Sobhee and Mr L Junye. Sincere thanks to Dr. Sujatha M, Dr. S. Bal and Mr S. Seeruttun for their help and guidance. We are also grateful to the University of Mauritius authorities for providing the fund.

Funding: this paper was partially funded by the University of Mauritius.

Received for publication: 24 April 2014.

Revision received: 19 May 2014.

Accepted for publication: 19 May 2014.

This work is licensed under a Creative Commons Attribution NonCommercial 3.0 License (CC BYNC 3.0).

(C) Copyright S. Rampadarath et al., 2014

Licensee PAGEPress srl, Italy

International Journal of Plant Biology 2014; 5:5448 doi:10.4081/pb.2014.5448

$7 \mathrm{~d}$, the hypocotyl $(1 \times 1 \mathrm{~cm})$ was dissected and inoculated on MS medium supplemented with different concentrations and combinations of 2,4 dichlorophenoxyacetic acid (2,4-D) and 6benzylaminopurine (BAP). The effect of the different combinations of PGRs on the weight and morphology of the calli were observed (Table 1).

\section{In vitro plant regeneration}

In this part of the study the concentration of PGRs used were kept constant (1.0 mg/L). Basal MS medium containing 3\% (w/v) sucrose and $0.8 \%(\mathrm{w} / \mathrm{v})$ agar was supplemented with either 2, 4-D, BAP or kinetin (K) alone and with combinations of either 2,4D \& BAP, 2,4D \& K or BAP $\&$ K. Shoot lengths were measured every $7 d$ from the day of inoculation and morphological differences of the developed plantlets were also observed. The lengths of the plants' shoots were measured at 7, 14 and 21d after transplantation using a Vernier calliper.

\section{Acclimatization}

After 21d healthy plantlets with well developed roots were thoroughly washed under running tap water and transplanted in a small lab- 
based greenhouse containing vermiculite as growing medium for hardening. The humidity level was kept at around $75 \%$ by spraying regularly. The plantlets were kept under this condition for a period of 2 weeks and then progressively exposed to increasing light intensity. The plantlets were afterwards transferred in pots containing soil and sand mixed at different ratios. The mixtures of sand and soil used were 1:1, 1:2 and 2:1. The plants were, again acclimatized for two weeks and then grown under field conditions. The shoot lengths were measured at day 15,30 and 45 after transplantation.

\section{Statistical analysis}

A completely randomized design was used in the study. Results were determined as mean \pm standard deviation. Normality tests for the recorded data were also performed. For the three different stages of seed maturity (5 replicates/PGRs concentration combinations), one way ANOVA tables (LSD at 5\%) were generated to test differences between mean parameters of seed and embryo morphology, the effect of the different concentration combinations of PGRs on the following characteristics: i) mean callus weight at three different time intervals (15, 30 and $45 \mathrm{~d})$, ii) mean shoot length for the in vitro plant regeneration at 7,14 and $21 \mathrm{~d}$ time intervals and iii) the effect of three different soil/sand mixtures ratios on shoot length of the plantlets regenerated in vitro. For the latter, there were 10 replicates per treatment. Minitab® (Minitab Inc., State College, PA, USA) 16.2.4 and Microsoft Excel ${ }^{\circledR}$ (Microsoft Co., Redmond, WA, USA) 2010 were used for the statistical analyses, and tables and graphs output.

\section{Results}

\section{Seeds and embryos characterization}

The immature, mature and fully mature seeds and embryos were physically characterized. All the parameters (weight, length and diameter) for both the seeds and embryos of different maturity stages varied significantly $(\mathrm{P}<0.05)$ (Table 2). The mean weights of the mature and fully mature seeds were between $0.774 \pm 0.143 \mathrm{~cm}$ and $0.832 \pm 0.077 \mathrm{~cm}$ respectively and that of immature embryo were 0.709 $\pm 0.074 \mathrm{~cm}$ (Table 2). An increase in mean weight and length of the seeds was observed as the seeds matured whereas the mature seeds had a larger diameter $(1.083 \pm 0.109 \mathrm{~cm})$. Moreover the mean diameter of the fully mature and mature embryos were about $0.2 \mathrm{~cm}$ larger to mean immature diameter embryos (Table 2).

\section{Callus induction}

Seven days after inoculation, the callus morphology and weights for the three different maturity stages of the seeds were recorded. At high concentration of $2,4 \mathrm{D}(3.0 \mathrm{mg} / \mathrm{L})$ and low concentration of BAP $(1.0 \mathrm{mg} / \mathrm{L})$ the callus formed were friable (Figure 1E,F). As the concentration of BAP increased from $1.0 \mathrm{mg} / \mathrm{L}$ to $3.0 \mathrm{mg} / \mathrm{L}$ and the concentration of $2,4 \mathrm{D}$ decreased from $3.0 \mathrm{mg} / \mathrm{L}$ to $1.0 \mathrm{mg} / \mathrm{L}$, the callus which developed was more compact and creamy greenish in color (Figure 1A). Variation in color was also observed as the concentration of 2,4-D increased (Figure $1 \mathrm{~B}, \mathrm{C})$ with formation of greener callus. The heaviest callus which was friable (Figure 1D) was obtained from the immature seeds.

The effect of varying MS with different concentration of PGRs had a significant response $(\mathrm{P}<0.05)$ on the weight of the callus for all treatments except for T7 at 15d, for treatments T1, T2, T3 and T9 at 30d and for treatments T3, $\mathrm{T} 4, \mathrm{~T} 7$ and $\mathrm{T} 9$ at $45 \mathrm{~d}$ (Table 3). Increasing the concentration of BAP $(3.0 \mathrm{mg} / \mathrm{L})$ and maintaining the concentration of 2,4D $(1.0(\mathrm{mg} / \mathrm{L})$, led to a decrease in the weight of the callus.

When a high concentration of 2,4D (3.0 $\mathrm{mg} / \mathrm{L}$ ) and a low concentration of BAP (1.0 $\mathrm{mg} / \mathrm{L}$ ) was used, the callus was heavier in all types of seeds after $30 \mathrm{~d}$ and $45 \mathrm{~d}$ of development. It was also noted that incremental increase in the concentration of 2,4D led to an increase in the weight of the callus, unlike BAP, where increasing its concentration caused the weight of the callus to decrease (Table 3). PGRs concentration that gave heavier callus $(5.62 \pm 1.18 \mathrm{~g})$ was in T7 at $45 \mathrm{~d}$.

Factors such as PGRs, seed maturity and time were found to play an important role in callus induction. Over time, significant differences in callus weight were obtained $(\mathrm{P}<0.05)$ (Table 3). Averaging the mean callus weight over time again showed that the heaviest callus was formed in T7 $(3.0 \mathrm{mg} / \mathrm{L} 2,4 \mathrm{D}$ and 1.0 $\mathrm{mg} / \mathrm{L}$ BAP) both for immature $(3.44 \pm 1.94 \mathrm{~g})$ and mature seeds $(3.47 \pm 1.77 \mathrm{~g})$ and in T8 (3.0 $\mathrm{mg} / \mathrm{L} \mathrm{2,4D}$ and $2.0 \mathrm{mg} / \mathrm{L} \mathrm{BAP)}$ for fully mature seeds $(3.61 \pm 0.87 \mathrm{~g})$ (Table 4$)$. Moreover averaging the mean callus weight over the PGRs, gave significant differences in callus weight
$(\mathrm{P}<0.05) \quad$ (Table 4). Immature seeds $(3.02 \pm 1.55 \mathrm{~g})$ had the largest callus weight compared to the other two at $45 \mathrm{~d}$. For fully mature seeds, there were no marked differences between the callus weight at $30 \mathrm{~d}$ $(2.40 \pm 1.30 \mathrm{~g})$ and $45 \mathrm{~d}(2.70 \pm 1.40 \mathrm{~g})$.

\section{In vitro plant regeneration}

The embryos of the seeds at the three stages of maturity were inoculated on 6 different MS medium supplemented with 2,4D, BAP and $\mathrm{K}$ at $1.0 \mathrm{mg} / \mathrm{L}$. Different PGRs had different effects on the morphology of plantlets formed in vitro. Plantlets formed on MS medium without any PGRs had long, thin shoots and formed roots (Figure 1G). Supplementing the medium with $1.0 \mathrm{mg} / \mathrm{L} \mathrm{2,4D}$ callus formation was observed instead of root formation (Figure $1 \mathrm{H}$ ). When BAP $(1.0 \mathrm{mg} / \mathrm{L})$ was added to the medium, dark green cotyledon leaves were formed along with a short hypocotyl and small roots (Figure 1I). K has a different effect on the embryo as only very large cotyledon leaves were formed.

After $21 \mathrm{~d}$ selected plantlets were used for acclimatization. Plantlets from mature seeds on the MS medium (Figure 1K), K (Figure 1L) and BAP (Figure 1M) were used for acclimatization. No rooting medium was required as all

Table 1. Concentrations and combinations of plant growth regulators used for callus induction.

\begin{tabular}{lcc} 
Treatment & 2,4-D ( $\mathrm{mg} / \mathrm{L})$ & BAP $(\mathrm{mg} / \mathrm{L})$ \\
T1 & 1.0 & 1.0 \\
T2 & 1.0 & 2.0 \\
\hline T3 & 1.0 & 3.0 \\
T4 & 2.0 & 1.0 \\
\hline T5 & 2.0 & 2.0 \\
T6 & 2.0 & 3.0 \\
\hline T7 & 3.0 & 1.0 \\
T8 & 3.0 & 2.0 \\
\hline T9 & 3.0 & 3.0 \\
\hline
\end{tabular}

Table 2. Characteristics of the seed and embryo of $J$. curcas harvested at three different maturity stages.

\begin{tabular}{|c|c|c|c|}
\hline \multirow[t]{2}{*}{ Parameters } & \multicolumn{3}{|c|}{ Maturity stages } \\
\hline & Immature & Mature & Fully mature \\
\hline \multicolumn{4}{|l|}{ Seed } \\
\hline Weight (g) & $0.709 \pm 0.074^{c^{*}}$ & $0.774 \pm 0.143^{b}$ & $0.832 \pm 0.077^{a}$ \\
\hline Length $(\mathrm{cm})$ & $1.707 \pm 0.102^{b}$ & $1.790 \pm 0.150^{\mathrm{a}}$ & $1.84 \pm 0.093^{\mathrm{a}}$ \\
\hline Diameter $(\mathrm{cm})$ & $0.877 \pm 0.125^{c}$ & $1.083 \pm 0.109^{a}$ & $0.950 \pm 0.068^{b}$ \\
\hline \multicolumn{4}{|l|}{ Embryo } \\
\hline Weight (g) & $0.03 \pm 0.02^{a}$ & $0.02 \pm 0.01^{\mathrm{b}}$ & $0.02 \pm 0.01^{b}$ \\
\hline Length $(\mathrm{cm})$ & $1.23 \pm 0.19^{\mathrm{b}}$ & $1.37 \pm 0.17^{a}$ & $1.37 \pm 0.33^{\mathrm{a}}$ \\
\hline Diameter $(\mathrm{cm})$ & $0.75 \pm 1.11^{\mathrm{a}}$ & $0.94 \pm 0.11^{\mathrm{b}}$ & $0.93 \pm 0.07^{\mathrm{b}}$ \\
\hline
\end{tabular}

One-way Anova at LSD 5\% level $(\mathrm{n}=30) .{ }^{*}$ Mean \pm standard deviation. Means that do not share same letter are significantly different. 
the plantlets selected for acclimatization had well developed roots. The only difference was that the roots formed on BAP medium was shorter and thicker compared to those on MS only or MS supplemented with K.
Significant differences in shoot length $(\mathrm{P}<0.05)$ were recorded for the seeds of different stages of maturity over a period of $21 \mathrm{~d}$ (Figure 2A). The best result was obtained when MS medium was used without any added PGRs. Mature seeds grown on MS medium produced the longest mean shoots $(11.13 \pm 1.95 \mathrm{~cm})$ followed by fully mature seeds with mean shoot length of $8.90 \pm 2.75$ $\mathrm{cm}$ (Figure 2A) at 21d. Seeds grown on PGRs
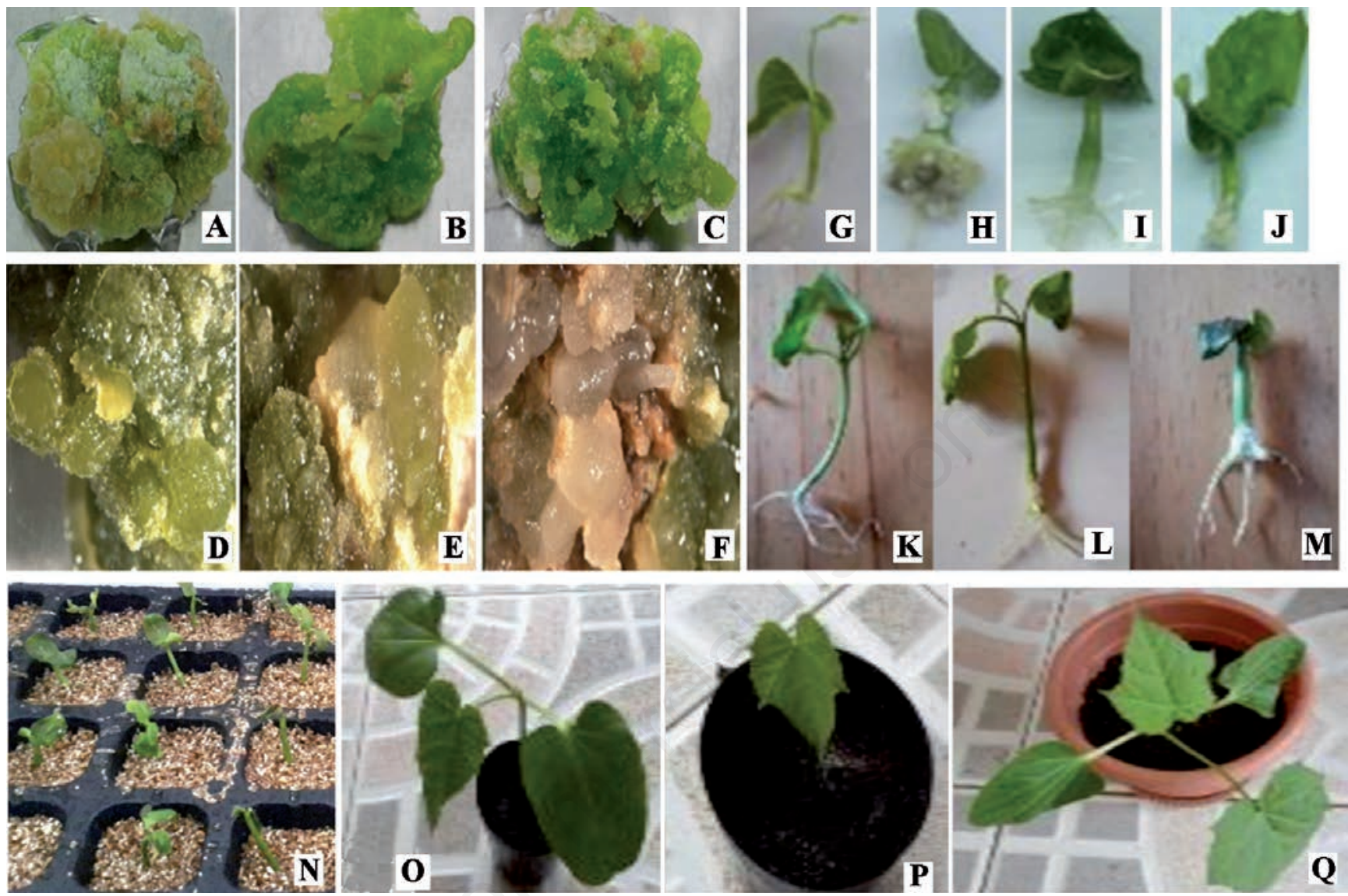

Figure 1. A-E) Morphological differences among calli of Jatropha carcas. A) T3; B) T6; C) T9; D) T7; E-F) T4. G-M) Morphology of the plantlets using either embryos or mature seeds as explants. G) MS only (embryo); H) MS+2,4-D (embryos); I) MS+BAP (embryos); J) MS+K (embryos); K) MS only (mature seeds); L) MS+K (mature seeds); M) MS+BAP (mature seeds). N-Q) Acclimatisation and transplantation. N) Acclimatisation in the small green house; $\mathrm{O}, \mathrm{P})$ plantlets transplanted after 2 weeks on 1.1 ratio of sand and soil; $\mathrm{Q}$ ) fully regenerated plant.

Table 3. Effect of different concentration of 2,4D and BAP on callus weight for seeds at different stages of maturity at the three time intervals.

\begin{tabular}{|c|c|c|c|c|c|c|c|c|c|}
\hline \multirow[t]{2}{*}{ Treatment } & \multicolumn{3}{|c|}{ Seed maturity stage (day 15) } & \multicolumn{3}{|c|}{ Seed maturity stage (day 30 ) } & \multicolumn{3}{|c|}{ Seed maturity stage (day 45) } \\
\hline & Immature & Mature & Fully mature & Immature & Mature & Fully mature & Immature & & Fully mature \\
\hline MS only & $0.13 \pm 0.18^{\mathrm{a}}$ & $0.04 \pm 0.02^{\mathrm{a}}$ & $0.05 \pm 0.02^{\mathrm{a}}$ & $0.34 \pm 0.16^{\mathrm{a}}$ & $0.32 \pm 0.08^{\mathrm{a}}$ & $0.34 \pm 0.16^{\mathrm{a}}$ & $0.49 \pm 0.14^{\mathrm{a}}$ & $0.38 \pm 0.08^{\mathrm{a}}$ & $0.49 \pm 0.14^{\mathrm{a}}$ \\
\hline 1 & $0.68 \pm 0.23^{\mathrm{a}}$ & $0.60 \pm 0.29^{\mathrm{a}}$ & $0.72 \pm 0.23^{\mathrm{a}}$ & $1.24 \pm 0.14^{b}$ & $1.18 \pm 0.07^{\mathrm{b}}$ & $1.59 \pm 0.34^{\mathrm{a}}$ & $1.93 \pm 0.47^{\mathrm{a}}$ & $1.95 \pm 0.34^{\mathrm{a}}$ & $2.17 \pm 0.46^{\mathrm{a}}$ \\
\hline 2 & $1.19 \pm 1.00^{b}$ & $0.92 \pm 0.79^{b}$ & $2.76 \pm 0.87^{\mathrm{a}}$ & $2.36 \pm 0.85^{\mathrm{a}}$ & $1.61 \pm 1.01^{\mathrm{a}}$ & $2.63 \pm 0.50^{\mathrm{a}}$ & $3.19 \pm 1.01^{\mathrm{a}}$ & $2.16 \pm 0.71^{\mathrm{a}}$ & $3.00 \pm 0.60^{\mathrm{a}}$ \\
\hline 3 & $2.72 \pm 0.56^{\mathrm{a}}$ & $0.83 \pm 0.87^{\mathrm{b}}$ & $1.09 \pm 0.78^{b}$ & $2.57 \pm 0.53^{b}$ & $1.42 \pm 0.63^{b}$ & $1.42 \pm 0.63^{\mathrm{a}}$ & $3.83 \pm 0.83^{b}$ & $1.52 \pm 1.25^{b}$ & $1.52 \pm 1.25^{\mathrm{a}}$ \\
\hline 4 & $0.91 \pm 0.48^{b}$ & $1.41 \pm 0.49^{a b}$ & $2.14 \pm 0.90^{\mathrm{a}}$ & $2.38 \pm 1.08^{\mathrm{a}}$ & $2.22 \pm 0.81^{\mathrm{a}}$ & $2.81 \pm 0.75^{\mathrm{a}}$ & $3.01 \pm 0.42^{\mathrm{b}}$ & $3.31 \pm 0.81^{\mathrm{ab}}$ & $3.97 \pm 0.72^{\mathrm{a}}$ \\
\hline 5 & $2.84 \pm 1.24^{b}$ & $1.03 \pm 0.32^{\mathrm{a}}$ & $1.06 \pm 0.34^{\mathrm{b}}$ & $3.14 \pm 1.71^{\mathrm{a}}$ & $1.97 \pm 0.99^{\mathrm{a}}$ & $1.97 \pm 0.99^{\mathrm{a}}$ & $3.82 \pm 1.78^{a}$ & $2.25 \pm 0.93^{\mathrm{a}}$ & $2.25 \pm 0.93^{\mathrm{a}}$ \\
\hline 6 & $1.63 \pm 0.61^{\mathrm{ab}}$ & $1.32 \pm 0.67^{b}$ & $2.42 \pm 0.72^{\mathrm{a}}$ & $2.91 \pm 1.23^{\mathrm{a}}$ & $2.92 \pm 0.86^{\mathrm{a}}$ & $3.86 \pm 0.27^{\mathrm{a}}$ & $3.08 \pm 0.80^{\mathrm{a}}$ & $3.49 \pm 0.55^{\mathrm{a}}$ & $3.61 \pm 0.67^{\mathrm{a}}$ \\
\hline 7 & $1.43 \pm 0.62^{\mathrm{a}}$ & $1.34 \pm 0.74^{\mathrm{a}}$ & $1.82 \pm 0.60^{\mathrm{a}}$ & $3.25 \pm 0.63^{\mathrm{a}}$ & $3.72 \pm 0.23^{\mathrm{a}}$ & $3.98 \pm 0.97^{\mathrm{a}}$ & $5.62 \pm 1.18^{b}$ & $5.32 \pm 0.53^{a b}$ & $4.00 \pm 1.27^{\mathrm{a}}$ \\
\hline 8 & $1.68 \pm 0.37^{b}$ & $1.85 \pm 0.08^{b}$ & $2.88 \pm 0.53^{\mathrm{a}}$ & $3.32 \pm 0.37^{\mathrm{a}}$ & $2.56 \pm 0.26^{\mathrm{b}}$ & $3.62 \pm 0.31^{\mathrm{a}}$ & $3.78 \pm 0.81^{\mathrm{a}}$ & $4.25 \pm 0.78^{a}$ & $4.34 \pm 0.97^{\mathrm{a}}$ \\
\hline 9 & $1.10 \pm 0.14^{\mathrm{a}}$ & $0.63 \pm 0.25^{b}$ & $1.28 \pm 0.20^{\mathrm{a}}$ & $1.88 \pm 0.17^{\mathrm{a}}$ & $1.16 \pm 0.50^{b}$ & $1.60 \pm 0.33^{\mathrm{ab}}$ & $2.82 \pm 1.21^{\mathrm{a}}$ & $1.49 \pm 0.35^{b}$ & $1.73 \pm 0.29^{b}$ \\
\hline
\end{tabular}

One way Anova with LSD comparison at 5\% to compare differences (small letter) in callus weight between seed maturity stages for each treatment and time intervals (d) $(\mathrm{n}=5)$ 
combinations $\mathrm{BAP} / \mathrm{K}$ and $2,4 \mathrm{D} / \mathrm{K}$ with $\mathrm{MS}$ medium gave very good shoot development. The length of shoots obtained on MS medium supplemented with BAP/K were $10.0 \pm 1.3 \mathrm{~cm}$ and $7.9 \pm 0.7 \mathrm{~cm}$, and supplemented with $2,4 \mathrm{D} / \mathrm{K}$ were $8.6 \pm 1.5 \mathrm{~cm}$ and $8.0 \pm 0.5 \mathrm{~cm}$ for mature and fully mature seeds respectively at $21 d$.

\section{Acclimatization and transplantation}

After $21 \mathrm{~d}$ the fully developed plantlets from the mature seeds were transferred to the green house (Figure 1N) containing the vermiculite medium. However, the plantlets from $\mathrm{K}$ and MS media wilted and died even though high initial humidity was maintained in the greenhouse. $86 \%$ of the plantlets that survived were those from BAP medium (Figure 1P).

After acclimatization, the plants were transferred on three soil and sand mixture ratio. The longest shoot length and good plantlets development growing on 1:1 ratio of sand and soil were observed (Figure 10,P). New plants were regenerated from in vitro plantlets of $J$. curcas with new leaves on well-developed long and strong stem (Figure 1Q).

Significant differences in shoot length $(\mathrm{P}<0.05)$ were observed on the 3 mixtures of soil and sand. Longest shoot length were recorded when sand and soil ratio was 1:1 (Figure 2B). For plantlets growing on soil/sand mixture ratios $1: 2$ and $2: 1$ the increase in the length of shoot with time was similar. Increase in shoot length from day 15 to 30 and 30 to 45 was about $3 \mathrm{~cm}$ for both mixtures ratio.

\section{Discussion}

\section{Morphology of the seeds} and embryo at different stages

\section{of maturity}

Morphology of both seeds and seed embryo varied with seed maturity. As the seed ripened the embryo size decreased, but gave good callus on different media hence can also be used for plantlet regeneration. This decrease in weight can be because of dehiscence but this did not affect the performance of the seed in vitro. ${ }^{11}$

\section{Callus induction}

Different explants have been used for callus induction in presence of different concentration of auxin and cytokinin and it was found that $J$. curcas gave better callus on medium with high concentration of auxins and cytokinin. ${ }^{12}$ In this study the observation did not agree with what has been reported in literature to date as better results were obtained on medium with a higher concentration of auxin, that is $3.0 \mathrm{mg} / \mathrm{L}$ of $2,4 \mathrm{D}$ and a lower concentration of BAP.
Table 4. Mean callus weight (g) averaged over both plant growth regulators combinations and time intervals (d) for the three different stages of seed maturity.

\begin{tabular}{lccc} 
Treatment & \multicolumn{3}{c}{ Seed maturity, mean \pm standard deviation } \\
Mature & Fully mature \\
1 & $1.26 \pm 0.63^{\mathrm{f}}$ & $1.28 \pm 0.59^{\mathrm{d}}$ & $1.49 \pm 0.70^{\mathrm{c}}$ \\
2 & $2.25 \pm 1.25^{\mathrm{de}}$ & $1.57 \pm 0.95^{\mathrm{d}}$ & $2.80 \pm 0.65^{\mathrm{b}}$ \\
\hline 3 & $3.05 \pm 0.84^{\mathrm{abc}}$ & $1.26 \pm 0.94^{\mathrm{d}}$ & $1.35 \pm 0.88^{\mathrm{c}}$ \\
4 & $2.10 \pm 1.13^{\mathrm{bc}}$ & $2.32 \pm 1.05^{\mathrm{bc}}$ & $2.30 \pm 1.08^{\mathrm{b}}$ \\
\hline 5 & $3.27 \pm 1.54^{\mathrm{ab}}$ & $1.76 \pm 0.93^{\mathrm{cd}}$ & $1.77 \pm 0.92^{\mathrm{c}}$ \\
6 & $2.54 \pm 1.08^{\mathrm{bcde}}$ & $2.58 \pm 1.15^{\mathrm{b}}$ & $3.30 \pm 0.85^{\mathrm{ab}}$ \\
\hline 7 & $3.44 \pm 1.94^{\mathrm{a}}$ & $3.47 \pm 1.77^{\mathrm{a}}$ & $3.27 \pm 0.85^{\mathrm{ab}}$ \\
\hline 8 & $2.93 \pm 1.07^{\mathrm{abcd}}$ & $2.89 \pm 1.13^{\mathrm{ab}}$ & $3.61 \pm 0.87^{\mathrm{a}}$ \\
\hline 9 & $1.94 \pm 0.98^{\mathrm{ef}}$ & $1.10 \pm 0.51^{\mathrm{d}}$ & $1.54 \pm 0.32^{\mathrm{c}}$ \\
MS only & $0.25 \pm 0.17^{\mathrm{g}}$ & $0.29 \pm 0.22^{\mathrm{e}}$ & $0.32 \pm 0.21^{\mathrm{d}}$ \\
\hline $\mathrm{d} 15$ & $1.42 \pm 1.02^{\mathrm{c}}$ & $1.00 \pm 0.69^{\mathrm{c}}$ & $1.63 \pm 1.03^{\mathrm{b}}$ \\
$\mathrm{d} 30$ & $2.47 \pm 1.30^{\mathrm{b}}$ & $1.93 \pm 1.15^{\mathrm{b}}$ & $2.40 \pm 1.30^{\mathrm{a}}$ \\
\hline $\mathrm{d} 45$ & $3.02 \pm 1.55^{\mathrm{a}}$ & $2.62 \pm 1.51^{\mathrm{a}}$ & $2.70 \pm 1.40^{\mathrm{a}}$ \\
\hline
\end{tabular}

One way Anova at LSD 5\% level; Means that do not share same letter are significantly different.

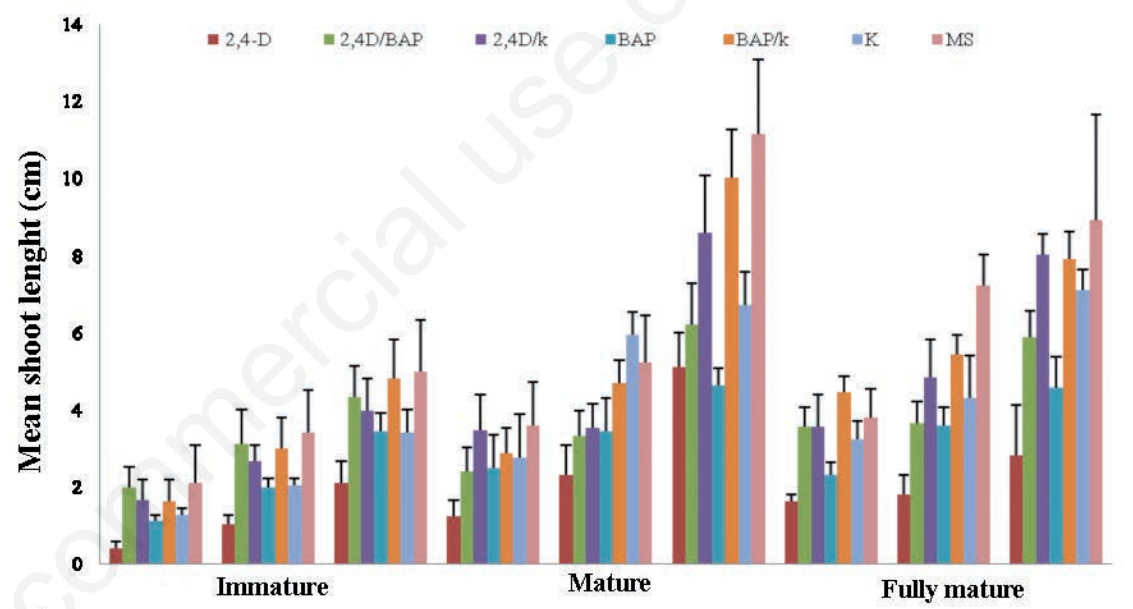

A

Seed maturuty

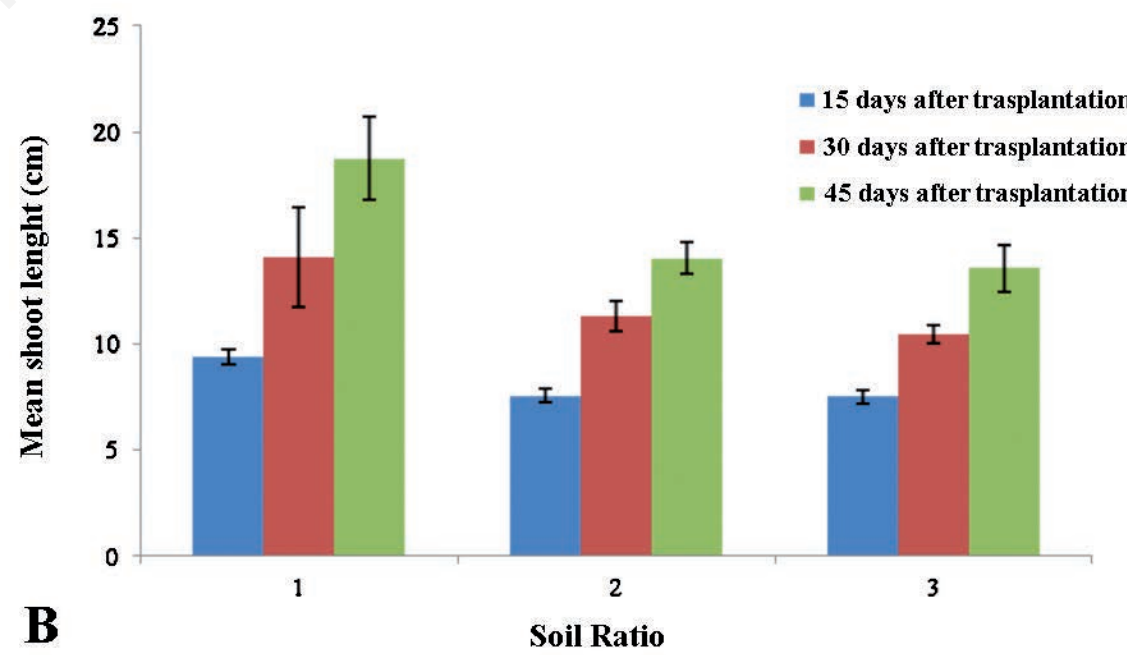

Figure 2. A) Effect of different plant growth regulators combinations (with fixed concentration of $1.0 \mathrm{mg} / \mathrm{L})$ on shoot length of the different seed maturity $(\mathrm{n}=20)$. B) Mean shoot length on the three sand and soil mixture ratios. Mean \pm standard deviation; One way Anova with LSD at 5\%, n=10. 
Seed maturity also played an important factor on callus weight. The increase in callus weight was higher during the period between 15-30d. Similar observation was also made by Chaudhary. ${ }^{13}$ They also reported that 2,4D, even at a low concentration gave very good results on the callus formation. This study confirms that at $1.0 \mathrm{mg} / \mathrm{L}$, callogenesis was occurring. Although similar explants were used, Chaudhary and co-workers observed that increasing the amount of 2,4D formed brownish callus, but no brownish callus was obtained in the present study. ${ }^{13}$

\section{Plant regeneration}

$J$. curcas is a xenogamic plant and it has a high degree of segregation, therefore breeding takes a long period of time to be achieved. There is also the problem of degeneration of hybrid embryos formed by the plant due to inadequate endosperm development. Hence, in vitro embryo rescue can be a very useful technique. However, the success of embryo rescue technique relies greatly on the maturation stage of the embryo and composition of the culture medium. Therefore, in this study the regeneration of in vitro plantlets using PGRs 2,4D, an auxin, and $\mathrm{K}$ and BAP as cytokinin has been demonstrated. The seven media used gave positive formation of shoots but morphological differences of the shoots obtained were observed. MS medium without PGRs also revealed to be a good medium since healthy plantlet were regenerated within 21d. Despite the fact that the MS generated plantlets did not survive acclimatization the result obtained can be used to explore further for the possibilities of the presence of, endogenous auxin and cytokinin present in the $J$. curcas L, embryo. ${ }^{14}$

It is known that rooting medium is important for tissue culture plantlets but in this study no specific rooting medium was required. Plantlets generated with good root formation from mature seeds were directly transferred for acclimatization. However, only plantlets regenerated on medium supplemented with BAP survived. These plantlets had a stronger root architecture compared to those grown on MS medium or on MS medium supplemented with K. In vitro root formation had also been observed by Sujatha and Mukta whereby within $8-10 \mathrm{~d} 88 \%$ of rooting was recorded. ${ }^{15}$

Although Warakagoda and Subasinghe used seeds at different stages of maturity for in vitro plant regeneration, extended study on different combination of PGRs have not been demonstrated. ${ }^{16}$ In vitro regeneration of plantlet is essential for mass propagation through either organogenesis or somatic embryogenesis and it requires good starting materials. The results showed that fully mature seeds can be used as explants for induction of callus. Although these seeds are at a dehiscence stage and the embryo lighter in weight, it is still viable and active in vitro. The concentration of 2,4D and BAP can be varied depending on the type of callus required either friable or compact.

A rapid method of in vitro embryo rescue was also recorded. Fully regenerated plantlets were obtained within $21 \mathrm{~d}$ of culture initiation on medium supplemented with BAP (1.0 $\mathrm{mg} / \mathrm{L})$. The plantlets were successfully acclimatized on a substrate consisting of sand and soil in the ratio of $1: 1$.

\section{Conclusions}

Seeds from all three stages of fruit maturity responded positively to callus induction and in vitro plant regeneration. Different callus morphology can be obtained by varying the 2,4D and BAP concentration. It was also shown that selecting the appropriate starting material is important in achieving the desired results. BAP only can be used at $1 \mathrm{mg} / \mathrm{L}$ without any rooting medium for in vitro plantlet regeneration within 21d. Further studies are required to optimize the findings presented here as tissue culture remains an important propagation tool for Jatropha curcas L.

\section{References}

1. Kalimuthu K, Paulsamy S, Senthilkumar $\mathrm{R}$, Sathya M. In vitro propagation of biodiesel plant of Jatropha curcas L. Plant Tissue Cult Biotech 2007;17:137-47.

2. Jha TB, Dafadar A, Chaudhuri RK. Somatic embryogenesis in Swertia chirata bunch. ham. ex wall-A multipotent medicinal herb. Asian J Biotechnol 2011;3:186-93

3. Tenenbaum D. Food vs. fuel: diversion of crops could cause more hunger. Environ Health Perspect 2008;116:A254-7.
4. Deore CA, Johnson ST. High frequency plant regeneration from leaf disc cultures of Jatropha curcas L.: an important biodiesel plant. Plant Biotechnol Rep 2008; 2:7-11

5. Karmee SK, Chadha A. Preparation of biodiesel from crude oil of Pongamia pinata. Biores Technol 2005;96:1425-9.

6. Heller J. Physic nut. Jatropha curcas L. Promoting the conservation and use of underutilized and neglected crops. 1996. Available from: http://www6.zetatalk.com/ docs/Crops/Promoting_Use_Of_Underutili zed_And_Neglected_Crops_1_Physic_Jatr opha_Nut_1996.pdf

7. Openshaw K. A review of Jatropha curcas: an oil plant of unfulfilled promise. Biomass Bioenerg 2000;19:1-15.

8. Purkayastha J, Sugla T, Paul A, et al. Efficient in vitro plant regeneration from shoot apices and gene transfer by particle bombardment in Jatropha curcas. Biol Plantarum 2010;54:13-20

9. Qin W, Wei-Da L, Yi L, et al. Plant regeneration from epicotyl explant of Jatropha curcas. J Plant Physiol Mol Biol 2004; 30:475-8.

10. Murashige T, Skoog F. A revised medium for rapid growth and bioassays with tobacco tissue cultures. Physiol Plant 1962; 15:473-97.

11. Morgan W, Ketring DL, Elmo M, Lipe JA. Functions of naturally produced ethylene in abscission, dehiscence and seed germination. In: Carr DJ, ed. Page Plant Growth Substances 1970. Heidelberg: Springer Verlag; 1972. pp 502-509.

12. Attaya AS, Geelen D, Belal El-Fatah H. Progress in Jatropha curcas tissue culture. Am-Eurasian J Sustain Agric 2012; 6:6-13.

13. Chaudhary FC, Qureshi KM, Chaudhary AH. Tissue culture studies in Jatropha curcas. Pakistan J Agric Res 1994;15:19-25.

14. Shukla P, Makwana V, Bhatt D, Robin P. Efficient method for direct and indirect organogenesis in biofuel crop Jatropha curcas. Int J Pharm Bio Sci 2013;4:673-82.

15. Sujatha M, Mukta N. Morphogenesis and plant regeneration from tissue cultures of Jatropha curcas. Plant Cell Tiss Organ Cult 1996;44:135-41.

16. Warakagoda PS, Subasinghe S. In vitro culture establishment and shoot proliferation of Jatropha curcas L. Trop Agr Res Extension 2009;12:77-80. 